\title{
KÜLTÜR ENDÜSTRISII KAVRAMI ÇERÇEVESİNDE MEDYA ÜRÜNLERİ: ELEŞTİREL YAKLAŞIM
}

\author{
Tolga KARA \\ Marmara Üniversitesi \\ tolgakara@marmara.edu.tr
}

\begin{abstract}
ÖZET
Medya ürünleri üzerine yapılan değerlendirmeler çoğu kez, bu ürün ve hizmetlerin iş karakterinin diğer endüstrilerden farksız olduğu varsayımı üzerine şekillenmektedir. Bu bakış açısına göre, otomobil ve mobilya ürünlerinin üretimindeki farklılıkların medya ürünleri için de geçerli olması gerekmektedir. Oysa medya ürünleri, doğaları gereği hem kendi aralarında hem de diğer ürünler ile aralarında, ekonomik çevreleri ve iş dinamikleri açısından, ciddi farklılıklar içermektedir. Bu makale, medya ürünlerinin karşılaștıkları güçlükleri, kendi aralarındaki ve diğer ürünlerle olan farklılıklarını ve medya endüstrilerindeki iş dinamiklerini Adorno ve Horkheimer'ın "Kültür Endüstrisi” kavramı çerçevesinde tartışmayı ve analiz etmeyi amaçlamaktadır. Öte yandan bu çalışmada, diğer endüstriler arasındaki arz ve talep farklılıklarına değinilmekte ve bu farklılıkların medya endüstrisi iş dinamiklerini nasıl etkilediği eleştirel bir gözle incelenmektedir.
\end{abstract}

Anahtar Kelimeler: Medyada Ürün Yönetimi, Medya Ekonomisi, Medya Endüstrisi ve Ürünleri

\section{MEDIA PRODUCTS IN THE CONTEXT OF CULTURE INDUSTRY: CRITICAL APPROACH}

\begin{abstract}
Considerations of media products sometimes assume that media share similar economic and business characteristics and that media are no different from other products and services. They express the view that no more differences need to be recognized for media then the kinds of differences observed between manufacturing automobiles and forniture products. This view is problematic, however, because media products differ significantly among themselves and because they operate in economic environments with business dynamics that most other products and services do not encounter. This article aims to discussion how media products differ among themselves and how those differences affect the economic forces they encounter and business dynamics of their industries in the context of Adorna and Horkheimer's "Culture Industry"concept. It also examined supply side and demand side differences between media and other products and how these affect media industry business dynamics.
\end{abstract}

Key Words: Product Management in Media, Media Economics, Media Industry and Product

\section{GİRIŞ}

Müşteri memnuniyeti odaklı serbest piyasa ekonomisinin gelişimine yön veren önemli noktalardan birisi de serbest rekabet faktörüdür. Serbest rekabet, makro anlamda toplu talebi dengeleyecek çok seçimliliği oluştururken, firma bazında ise yeni veya geliştirilmiş, fonksiyonel ürün kavramını meydana getirmektedir. Dolayısıyla ürün yönetimi, artık çağdaş firmaların en önemli sorunu olmakta ve bu sorun üzerine büyük çapta bütçe ayırmaları kaçınılmaz hale gelmektedir.

Teknolojinin sınırsız olanakları sayesinde medya endüstrisi her geçen gün daha da büyümekte ve dönüşmektedir. Teknoloji ile birlikte endüstrinin temel işleyişi de değişime uğramış fakat en büyük etki, medya ürünlerinin çeşitliliğinde yaşanmıştır. Geleneksel medya ürünlerinin yanında, yeni medya teknolojilerinin ürünleri de pazarda tüketicilerle buluşmuştur. Bu da, yönetilmesi gereken daha geniş ve daha karmaşık bir ürün yelpazesi anlamına gelmektedir. 
Medya endüstrisindeki ürünlere özel farklılıklar, medya ürünlerinin standart ekonomi, finans ya da muhasebe ilkelerine, ilgili kanun ve düzenlemelere tabi olmadıkları anlamına gelmemektedir. Bununla birlikte, aynı ürünün farklı mecralara uygulanması, ürünlerin doğaları gereği birtakım doku uyuşmazlıklarının ortaya çıkmasına sebep olmuş ve bu uyuşmazlıkların analizini zorunlu kılmıştır.

Fakat diğer yandan, Adorno ve Horkheimer'ın kültür endüstrisi kavramsallaştırması gibi kadim medya teorilerinin etkileri geçmişte olduğu gibi günümüzde de medya ürünlerinin içeriğini belirlemektedir. Kapitalizm, etkinliğini sadece ekonomik düzeyde kabul ettirmekle yetinmez; aynı zamanda yaşamın tüm alanını da rasyonelleştirerek, metalaştırarak ve şeyleştirerek bünyesine dahil etme çabası içindedir. Bu amaçla duyguların ve arzuların sistemin içinde kontrol altına alınması ve yönlendirilmesi modernizmin öngördüğü toplumsallaştırmanın kaçınılmaz bir gerekliliğidir. Kitaplar, müzik CD'leri, sinema filmleri, gazete haberleri, dergiler, video oyunları ve TV sovları gibi medya ürünleri de içeriğindeki ideolojik ve ekonomik niteliklerinden dolayı kapitalizmin devamında hayati öneme sahip olan kültür endüstrisi tarafindan kutsanan ürünlerin başında gelmektedir.

Gündelik hayat, bağımlı sınıflarla egemen sınıfların bir arada yaşadığı, içeriği belirleyenlerle içerikten etkilenenlerin yan yana geldiği, tahakküm ve direnişin aynı anda var olduğu ve tüm ideolojik biçimlerin işlendiği bir zemindir. Gündelik hayatın her alanına yayılmış medya ürünlerinin ideolojik yapısı ve bu hakim ideolojinin devamını gözeten ürün yönetim biçimleri, toplumda varolan iktidar yapılanmasının devamına ilişkin önemli ipuçları içermektedir. Bu çalışma ekseninde medya ürünleri de kültür endüstrisi tarafından oluşturulmuş -aslında daha ziyade manipüle edilmiş- ve şeyleştirilmiş bir olgu, bir ideoloji olarak ele alınmakta ve bu olgunun ardındaki hakim ideolojik iklimin devamı amacıyla üretim süreçleri ve üretim yönetimi kapsamında eleştirel bir gözle irdelenmiştir.

\section{KÜLTÜR ENDÜSTRİSI KAVRAMI}

Frankfurt Okulu ve diğer bir adlandırmayla Eleştirel Teori, temel olarak doğaya üstünlük atfeden, insanları efsane ve mitlerden kurtaran ve neticede bireyi, insani olmayan belirlenmiş ilişkiler yasasına mahkum eden Aydınlanma geleneğine yönelttikleri totaliterlik iddiaları ile düşünce dünyasında yerlerini almışlardır (Larrain, 1995: 80 ). Bu anlamda Marksist yönelimli ilk araştırma merkezi olan Frankfurt Okulu ve buradaki sosyal bilimciler ağırlıklı olarak Marx'ın ekonomi politik, meta fetişizmi ve yabancılaşma kavramlarının gündelik hayatta iktidar ve medya tarafindan nasıl tekrar tekrar üretildiklerine dikkat çekmektedirler. Eleştirel kuramla özdeşleştirilen kültür endüstrisi kavramı ilk kez Thedor Adorno ve Marx Horkheimer'in ortak kitabı "Aydınlanmanın Diyalektiği” eserinde kullanılmıştır (Adorno, 2003:12). Adorno, Horkheimer ve diğer Frankfurt Okulu düşünürleri 20. yüzyılda tahakkümün kültürel boyutu, gündelik hayatın estetize edilmesi, kültürün ticarileşmesi, standartlaşması ve toplumsal yabancılaşma üzerine çalışmışlardır. Adorno ve Horkheimer'a göre hayatın her alanı, kültür endüstrisi tarafından metalaştırılmakta ve böylelikle hakim ideoloji hem ekonomik hem de ideolojik olarak kitlelerin bilincinde yeniden üretilmektedir.

Kültür endüstrisi kuramına göre, kitle kültürü insan bireyselliğini tehdit etmektedir. Bireyi edilgin bir kültür tüketicisi konumuna getiren kütle kültürü sanat, eğlence, dinlenme, boş zamanları değerlendirme gibi yaşam pratiklerini birer tüketim eylemine dönüştürmektedir. Adorno ve Horkheimer medyayı, iktidar ilişkilerinin oluşturulduğu, korunduğu, çoğaltılarak dağıtıldığı kısacası iktidarın olumladığı ve iktidar tarafından da beslenen bir endüstri olarak görürler (Adorno, 2007; 74).

Adorno, örneğini pop müzik ve kültür endüstrisi olarak verdiği, teknik olarak yeniden üretilmiş sanatı küçümsemektedir. O'na göre, kültür endüstrisi, "modern sanayi toplumunun homojenleşmiş ve rasyonelleşmiş dünyasının düzgün işlemesine yardımcı olma işlevine sahipti ve bu nedenle vardı. $\mathrm{Bu}$ amaçla, kültür endüstrisi, "vaat ettiğini yerine getirmeyen sahte tatminler dağıtmakta", insanları kandırmaktadır. İşte bu nedenle, Adorno, sanat eserleri ile kültür endüstrisini şöyle birbirinden ayırmaktadır: "sanat eserleri, çileci ve utançsızdır; kültür endüstrisi ise, pornografiktir ve iffet taslar" (Lunn'dan aktaran Kayıkçı, 2007:28).

Öte yandan Horkheimer ise kültür endüstrisinin atomize edici, kitleselleştirici yönüne vurgu yapmaktadır. O'na göre bugün, hayatın tümü artan ölçüde rasyonelleştirilmekte ve planlanmaktadır. 
Aynı şekilde tek tek her bireyin hayatı da geçmişte özel dünyasını oluşturan ne varsa rasyonelleştirmeye ve planlamaya dahil edilmektedir. Bu yüzden bugün, bireyin var olabilmesi için sistemin varlığına uyum göstermesi gerekmektedir. Toplumdan kaçacak yeri kalmamıştır. Bireyi buna mahkum eden ise bilinçli bir azınlığın planlayarak ürettiği kültürel ürenlerdir (Horkheimer, 1996:122). Bu bağlamda değerlendirildiğinde kapitalizm, her şeyden öte meta üreten bir sistemdir. Dolayısıyla ana hedeflerden biri üretilen metaların doğal görünmesini sağlamaktır. Bu görev de birer meta olarak değerlendirilebilecek medya ürünlerinin üretimini yönetenlere düşmektedir. Diğer yandan, toplumsal ilişkilerden sanatsal üretime kadar şeyleştirme sürecinin işlemesi metalaşmanın temelini oluşturmaktadır. Bu temel içinde ana hedeflerden biri de sınıf bilinçlerinin yok olması ve atomize hareket eden, fazla düşünmeyen, kitlesel eğlenceler üzerine odaklanan ve bunlarla zaman geçiren insan toplulukları yaratılmasıdır. İnsanoğlunun kendi düşünsel gücüyle yaratılan metalara insanüstü bir ilahi güç atfederek onları yüceleştirmek de şeyleştirmenin ana hedefidir (Adorno, 2007; 101). Böylece insanlar kendi ürettikleri endütriyel ürünlerin yani aslında 'şey'lerin esiri haline gelmektedirler. Şeyleşme, günümüzün sosyo-kültürel ortamının en belirgin özelliğidir. Medya endüstrisinin ürünleri de benzer bir şeyleştirmenin öznesi konumundadır.

\section{KÜLTÜR ENDÜSTRİSINIIN ÜRETICIISI OLARAK MEDYA}

Genel olarak ürün, bir istek veya ihtiyacı tatmin etmek üzere tüketim, kullanım veya dikkat çekme amacıyla pazara sunulan herhangi bir şeydir ve fiziksel objeleri, hizmetleri, kişileri, yerleri, örgütleri veya fikirleri kapsamaktadır. (Kotler, 1987:234) Bu çerçevede ürün, tüketici ürünleri ve endüstriyel ürünler olmak üzere iki sınıflamaya ayrılabilir.

Ekonomi ya da pazarlama çalışmalarında ise ürün genellikle, bir tür mülkiyet ya da özellik düzenlemesi olarak tanımlanmaktadır. (Ziggers, 2005:45) Bu yüzden ürün yönetimi, farklı beklentileri veya hedef piyasaların ihtiyaçlarını karşılama noktasında önemli bir rol oynamaktadır. Çünkü, modern pazarlama ilkeleri gereği ihtiyaç ve beklentilerin sürdürülebilir olması gerekmektedir. (Ittner ve ark., 2009:19) Bu noktadan hareketle, ürünü etkileyen her karar, hem ürünün doğasına ilişkin olmalı hem de farklı beklenti ve ihtiyaçları karşılamalıdır. Öte yandan, ürün hakkında alınan her karar, aynı zamanda ürünün kendisini de etkileyecektir. Fakat, medya ürünleri söz konusu olduğunda bu durum her zaman bu şekilde işlemeyebilir. Medya ürünlerinin kendine has ve karmaşık yapısı, ürün hakkındaki karar süreçlerini de etkilemektedir.

Genel olarak medya ürünleri iki temel bileşenden meydana gelmektedir. Bunlardan ilki; kurgusal, editöryal haldeki işlenmemiş maddi olmayan içerik bileşenleri, diğeri ise tüketicinin eline ulaşan fiziksel, maddi bileşenlerdir.(Picard, 2005a: 31) Bileşenlerden ilki içeriğe, diğeri ise fiziksel olarak erişilebilirliğe vurgu yapmaktadır. Öte yandan, medya ürünlerinin en temel özelliği eğlendirici, ikna edici veya bilgilendirici özellikleri ile potansiyel müşterilerinin gereksinimlerini karşılayabilme ve onları memnun edebilme yetisidir. Adorno'ya göre bu memnuniyet mümkün olan en düşük beğeni düzeyinde standardize edilmiştir çünkü sistem tüketicinin içerik üzerine fazlaca kafa yormasını istememektedir. Kültür endüstrisi tarafından gelir guruplarına göre birer istatistik öğesi haline getirilen tüketicilerin, neyi izleyeceği ya da dinleyeceği önceden bilindiğinden, bu ürünlerin ulaştığ kitleler de bu ürünleri ona göre alıp tüketmektedir. Kültür endüstrisi uzmanları tarafindan hazırlanan bu ürünlerde, örneğin filmlerde, filmin nasıl biteceği, filmde kimin cezalandırılacağı tahmin edilebilmekte ve bu tahminler doğru çıktığında kitleler mutlu olmaktadır. Böylece varolan toplumsal yaşam, kitlelere kültür endüstrisi süzgecinden geçirilerek sunulmuş olmaktadır (Adorno, 2003:12). Diğer yandan "Tek Boyutlu İnsan" eserinde Herbert Marcuse, medya ürünleri dolayımlı içeriğin, insanı ve dolayısıyla toplumu tek tipleştireceğini ve böylece egemen gücün hakimiyet alanını daha efektif biçimde genişletebileceğini savunmaktadır (Marcuse, 1997: 97).

Medya ürünleri, farklı kullanım alanlarında farklı karakteristik özellikler göstermektedir. Temel olarak medya ürünleri, tek kullanımlık ürünler ve sürekli ürünler olmak üzere iki kategoriye ayrilabilir.

Tek kullanımlık ürünler, benzersiz bir içeriğe dayalı yaratıcı, fikir odaklı ürünlerdir. Kitaplar, vizyon filmleri, albümler ve dijital oyunlar bu kategoriye örnek olarak verilebilir. Bu tarz ürünlerin tüketici 
açısından ikinci kez kullanımı, tüketiciye aynı faydayı sağlamayacaktır. Fakat bu ürünler, tek seferlik kullanıma mahsus olarak üretilmiş olsa da, arka planda yoğun bir proje çalışması gerektirmektedir. $\mathrm{Bu}$ sebeple, bu ürünlerin yönetimi aynı zamanda proje yönetimini de gerektirmektedir. (Picard, 2005b: 61)

Tek kullanımlık medya ürünlerinin yönetimi açısından en riskli noktalardan bir diğeri ise, ürünlerin kararsız bir hedef kitleye hitap ediyor olmasıdır. $\mathrm{Bu}$ tarz ürünlerin tüketicileri konjonktürel değişimler, moda akımları ya da arkadaş tavsiyesi gibi dış faktörlerden kolay etkilenmekte ve tüketim alışkanlıklarını değiştirebilmektedir.

Tek kullanımlık ürünlerin tam tersi olarak, sürekli ürünler ise; değişen içerik yapısıyla bir döngüyü takip eden, periyodik olarak üretilen medya ürünlerini kapsamaktadır. Bu gruba örnek olarak dergiler, gazeteler, televizyon dizileri ya da programları verilebilir. Kısıtlı zaman aralığında üretilmek zorunda olan bu tür medya ürünleri, koordineli ve disiplinli bir süreç yönetimine ihtiyaç duymaktadır. Zira, bu tür ürünleri üreten medya işletmelerinde ürün yönetimi, içerik oluşturmanın ötesinde, içeriğin seçimi ve sürecin yönetimi ile ilgilidir. Eleştirel ekonomi politik geleneğin önemli düşünürlerinden Herman ve Chomsky'e (1988) göre, iletişim ve enformasyon teknolojileri mevcut güç ve iktidar ilişkileri çerçevesinde geliştirilmekte ve kullanılmaktadır. Medya, iletişim teknolojileri ve genel anlamda kültürel üretim alanı sermayeye bağlıdır ve onun tarafından sınırlandırılmaktadır. Sermaye, geliştirilen teknolojiyi (Ar-Ge) ve yaratılan içeriği etkilemektedir. Bu bağlamda ekonomi politik yaklaşım, iletişim teknolojilerinin nereden kaynaklandığını ve içeriklerin niçin o şekilde oluştuğunu anlamada faydalı bir çerçeve sunmaktadır.

Sürekli ürünler kategorideki ürünlerin en temel gereksinimlerinden biri de markadır. Doğaldır ki bir gazetenin ya da bir televizyon dizisinin, bir kitaptan veya sinema filminden daha fazla markaya ihtiyacı vardır. Bu durum, medyada ürün yönetimi açısından marka yönetimini de gerekli kılmaktadır. Fakat diğer yandan, medya ürünlerinin markalaşması kadar medyanın markalaşmayı teşviki de gözden kaçmaması gereken bir konudur. Büyük firmalar küresel pazarda mallarını satmak için bir güç uygulamaktadır. Tekelci firmalar tüketicilerin gözünde reklamlar yoluyla ürün farklılaşması yaratmaktadır. Marka ismi, müseccel marka, markaya özgü ambalaj, paketleme, stil ve model değişiklikleri yaratılarak tüketicilerin algıları yönlendirilmekte ve böylece kâr marjları yükseltilmekte, daha çok büyüme sağlanmakta ve küçük rakipler pazarın dışına atılmaktadır. Bu süreç, fiyat rekabetinin yerini almakta, satılabilir görünüş ve marka yaratma daha yaygın bir rekabet biçimi haline gelmektedir. Reklamlar yoluyla tekelci kapitalizm koşulları altında talep yönetimi yapılarak üretim ve tüketim artırılmakta ve bu yolla artı-değerin sermaye tarafindan sömürülmesi sağlanmaktadır (Yaylagül, 2013:227). Kapitalist sistemin kendisini genişletilmiş olarak yeniden üretebilmesi için tüketime ihtiyaç vardır, onun için kapitalist sistem imkân bulduğu bütün kanal ve ortamları kullanarak tüketimi besler. İnternet de dahil olmak üzere bütün iletişim ortamları ürün ve hizmetlerin reklamları ile doludur. Böylece reklamlar aracılığıyla tüketim ideolojisi kullanılarak kişisel sorunların çözümü için tüketicilere markalı ürünlerin tüketimi önerilir.

Fakat buna karşın, tek kullanımlık ürünlerin tam aksine, süreklilik arz eden ürünler daha az pazarlama ve satış çabasına ihtiyaç duymakta hatta daha az satış ve pazarlama bütçesi gerektirmektedir. Bunun nedeni olarak, bu tarz ürünlerin tüketicide bir alışkanlık oluşturması ve tüketiciye belli oranda kolaylık sağlayan abonelik tarzı dağıtım modelleri gösterilebilir. Bir kez üretildikten ve tüketici gözünde belirli bir alışkanlık düzeyi oluştuktan sonra bu ürünlerin başarısızlık oranları oldukça düşüktür. (Picard, 2005b: 62)

Medya ürünlerindeki yönetimsel farkları belirginleştiren "tek kullanımlık" ve "sürekli ürün" kategorilerinin dışında, mecralardaki çeşitlilik ve ürünlerin kendine has özellikleri sonucu oluşan bir takım kategorilerden de bahsetmek mümkündür. Bu kategoriler; enformasyon malları olarak medya ürünleri ve ikili ya da çoklu mallar olarak medya ürünleri şeklinde sıralanabilir. Bu kategorizasyon, medyada ürün yönetimi açısından belirgin ayrımlara işaret etmektedir. 


\section{KÜRESELLEŞME VE ENFORMASYON TEKNOLOJILERİ ETKİSI}

İletişim ve enformasyon teknolojilerinin her geçen gün gelişmesi ve küreselleşmesi medya ürünlerinin de farklılaşmasına ve dijitalleşmesine neden olmuştur. Bugün sıklıkla kullanılan geleneksel medya ve yeni medya kavramsallaştırması bir anlamda bu dönüşümün bir ifadesidir. Lev Manovich "The Language of New Media" kitabında geleneksel medyanın karşısına çıkan bu yeni mecrayı sayısal temsil, modülerlik, otomasyon, değişkenlik ve kod çevrimi kavramlarıyla açıklamaktadır (Manovich. 2001:34). Dolayısıyla medya ürünleri de bu yeni konsept etrafinda yeniden biçimlenmektedir. Küreselleşme ise en yalın haliyle teknolojinin yöndeşmesi, uluslararasılaşma ve açık bir ticaret sistemi olarak ifade edilebilir. Fakat küreselleşmeye sadece teknoloji ve teknolojinin gelişimi çerçevesinde yaklaşmak hatalı olacaktır. Küresel kültür kavramının yaratıcısı sayılan Anthony Giddens'a göre küreselleşme sadece teknolojik değil, ekonomik, siyasal ve kültürel/ideolojik bir süreçtir (Giddens, 2006:50). Giddens'in iletişim teknolojilerindeki hızlı gelişmelerle birlikte dünya iletişim düzeninin de yeni bir sürece girdiğini ifade etmesi, bir çok düşünür tarafından da yeni iletişim düzeni olarak yorumlanmasına neden olmuştur. Giddens ve ona katılanların küreselleşme güzellemelerine karşın; Mattelart'ın yeni iletişim teknolojilerini, medya endüstrisini ve reklam sektörünü Althusser'i anımsatırcasına emperyalizmin ideolojik ve küresel aygıtları olarak nitelemesi ise dikkat çekicidir (Mattelart, 1979: 257). Çünkü küreselleşme, merkezden çevreye doğru yayılan; merkezde olanların daima kazandığı ve çevreye doğru kaybedenlerin ortaya çıktığı yeni bir kapitalist düzendir. Bu süreçte uluslararası ticaret yollarını, iletişim kanallarını, üretim ve dağıtım zincirlerini merkez ülkelere ait küresel şirketler kontrol etmektedir. Bilgi ve iletişim teknolojileri de gerek donanım gerekse de içerik olarak tekelci şirketlerin denetimindedir. Küreselleşme sürecinde gümrük ve tarifeler kaldırılırken çevre ülkeler açık pazar haline getirilmektedir. Söz konusu araçlarla kültürel üretimin uluslararası bir nitelik kazandığı görülmektedir. Ancak bu, ABD merkezli bir uluslararası kültürel üretimdir. Kitle iletişim teknolojilerinin, çokuluslu bir görünüm sergileseler bile ağırlıklı olarak Amerika'nın mülkiyetinde bulunmaları, kitle iletişim ortamında üretilen ve dünyaya dağıtılan kitle kültürünün de Amerikan merkezli olması gerçeğini ortaya çıkarmıştır. Küresel bir araç olarak internet, içeriklerin izinsiz yayınına imkân sağlayıp bilginin ucuzlamasına, dağıtımının, kopyalanmasının ve yeniden şekillendirilmesinin kolaylaşmasını kolaylaştırsa da, yine de güçlü aktörler daha yaratıcı yöntemleri kullanarak bilgiyi kontrol etmekte, ticarî mal haline getirmekte ve satmaktadır. Bunun yöntemi ise, bilgiyi özel mülkiyet düzeninin bir parçası haline getirerek sadece bedelini ödeyenlerin sahip olabileceği bir emtia haline getirmektir. Bilginin küresel sahipleri -ki bunlar büyük yayın evleri, medya şirketleri ve sosyal medya ağları olabilir- sözleşme ve güvence sistemi gibi yollarla bilgiyi kendi denetimlerinde tutmaktadırlar. Böylece kamusal olması gereken bilgi havuzu sermayenin elinde birikmekte ve pazarlanmaktadır (Shapiro, 1999:16).

Teknoloji ve kültür alanında meydana gelen değişim ekonomide de yoğun bir şekilde hissedilmektedir. İşlerin çoğu hizmet endüstrisine kaymıştır. Yeni teknolojilerle iletişim ve enformasyonun geliştirilmesi, işlenmesi ve yönlendirilmesi çok daha kolaylaşmıştır. Enformasyon teknolojilerindeki gelişme ve değişme, dünyanın ekonomik ve siyasi düzenini de değiştirmiştir. İş̧ dünyası daha dinamik ve rekabetçi hale gelirken kurumsal yapılar daha pazar odaklı bir hale gelmektedir (Wade,1993:4). İnternet ve enformasyon teknolojileri verimliliği artırmıştır. Fakat aynı zamanda medya ürünlerinin çeşitliliğini de arttırmış gibi görünmekle birlikte içerikler birbirine yaklaşmış ve standartlaşmıştır.

\section{ENFORMASYON MALLARI OLARAK MEDYA ÜRÜNLERİ}

Enformasyon malları olarak medya ürünleri için bir tanım vermeden önce, enformasyonun ne olduğu konusuna değinmek gerekir. Enformasyon, en genel haliyle, işlenmiş biçimdeki veriler olarak ele alınabilir. Enformasyon, bir diğer tanımda; "karar birimleri arasında iletişime konu olabilen, indirgenmiş ve dönüştürülmüş bilgi" olarak ele alınmaktadır (Etzioni 2008:164). Bu tanım, bilgi (knowledge) ile enformasyon (information) arasında bir fark olduğunu ortaya koymaktadır. Bu fark, enformasyonun işlenmiş bilgi olmasından kaynaklanmaktadır. Saphiro ve Varian'a göre ise enformasyon, "sayısallaştırılabilen ve parçalar halinde kodlanabilen herşey"i kapsamaktadır. (Saphiro ve Varian 1999:3) Saphiro ve Varian'nın tanımı esas alındığında, enformasyon malları; "ticari bir işleme konu olan herhangi bir enformasyon" şeklinde ifade edilebilir. Aynı zamanda enformasyon malları, bilgi malları olarak da adlandırılan mal grubunu işaret etmektedir. Bu tanımıyla kitaplar, 
müzik CD’leri, yazılımlar, borsa bilgileri, haberler vb. ürünlerin hepsi enformasyon mallarına birer örnek teşkil etmektedir.

Varian'a göre, enformasyon mallarının üç temel özelliği bulunmaktadır. Enformasyon malları (1) tecrübe mallarıdır, (2) ölçek ekonomilerine maruzdurlar ve (3) toplumsal mallarla benzerlikler göstermektedirler. (Saphiro ve Varian 1999:24)

Öncelikle, medya ürünleri sadece tüketildiklerinde değerlerini ortaya koyan tecrübe malları grubundadır. (Clemons, 2008:24) Dolayısıyla bu durum, ürünün ve ürün yönetiminin, tüketicilerin güvenini kazanması gerektiği gerçeğini ortaya çıkarmaktadır. Bu ise ancak, zamanla devam eden öğrenme süreci içinde oluşacak ya da değiştirilecek değer yargılarını, (fiyat/kalite performansı) uygun biçimde keşfederek yapılabilir. Müzik marketten bir müzik CD'si ya da kitapçıdan bir kitap satın almış olmak, o malın tüketildiği anlamına gelmemektedir. Malın tüketimi, CD’nin dinlenmesi ya da kitabın okunması sonucu ortaya çıkacaktır. Daha açık bir ifadeyle tüketebilmek için tecrübe etmek gerekmektedir. Bununla birlikte, birçok medya ürünü inanç temeline dayalı davranışlar sergilemektedir. Tüketiciler genelde, kendilerine sunulan ürünü, ihtiyaçları olan ürüne kıyaslayarak değerlendirmemektedir. (Doyle, 2002:11)

Enformasyon malları ölçek ekonomilerine tabidirler. (Doherty, 2010: 397) Ölçek, üretilen ürün miktarı ya da üretim biriminin toplam kapasitesidir. Ölçek ekonomisi ise artan üretim kapasitesi sonucu sabit maliyetlerin azalarak, verimliliğin artmasıdır. (Sullivan, 2003:157) Bu yüzden, ölçek ekonomisi denince maliyetin en aza indirildiği üretim kapasitesini oluşturan fabrika büyüklüğü akla gelmektedir. Üretimde miktar arttıkça, işgücünün ve makinaların uzmanlaşması sonucu maliyetin düştüğü kabul edilmiş, böylece fabrika ölçeğinin bu maliyet düşürücü etkisi, ölçeğin getirdiği ekonomi olarak adlandırılmıştır (Tayler, 2009:200). Medya ürünleri açısından, ilk baskılar için yüksek sabit üretim maliyetleri ve bazı durumlarda, neredeyse yeniden üretimde fark edilemeyen çeşitli değişken maliyetler söz konusudur. Bu yapı, son birim maliyetlerinin, tüketimi artan kalemlerin de artması ile beraber, düzenli olarak azalmasına (ölçek ekonomisi prensibi) olanak tanımaktadır. Yine bu yapı, farklı formattaki bir ürün gibi riskli bir girişimin, yeniden satılmasını da mümkün kılmaktadır. (Doyle, 2002:13-15) Öte yandan, bu ekonomik yapının paralel olmayan karakteri yüzünden, yüksek miktarlardaki medya ürünleri için (Doherty, 2010: 221) çapraz finansman yapmak da çok önemlidir. Buna dayanak olarak, satış gelirinin üretimi finanse etmek için yetersiz olacağı fikri temel olarak gösterilmektedir.

Enformasyon malları, rekabetçi kamu mallarında sıklıkla görülen özellikleri taşımaktadır. Konuya medya perspektifiyle yaklaşıldığında, bireysel tüketimin ve rekabetle yüzleşmenin farklı yolları ortaya çıkmaktadır. Karasal yayın yapan televizyon ve radyolar genellikle kamu malları olarak kabul edilirken; müzik ve sinema, kişisel kullanıma yatkınlıkları nedeniyle daha çok özel mallar olarak kabul edilmektedir. Bunun arkasında yatan sebep olarak, içerik tüketiminin aslında rekabete tabi olmaması; fakat, o içeriği sunmak ya da almak için kullanılan dağıtım kanalının rekabete tabi olması gösterilebilir. (Albarran, Arrese, 2003:73) Yani aslında rekabete konu olan, içeriğin sunulduğu ortamdır. Aynı şekilde, dijital televizyon platformlarında bu durum, sinema ve müzik endüstrisine benzer bir özellik sergilemektedir. Nasıl ki bir filmi sinemada izlemek için ödeme yapmak ya da bir sanatçıyı dinlemek için albümünü satın almak gerekiyorsa, dijital TV platformlarını da izlemek için ücret ödemek gerekmektedir.

Ancak, medya ürünlerinin özel ya da kamu ayrımına karar verirken, bu ürünlerin birçoğunun, özünde kendine ait bir karakteristiği barındırdığını unutmamak gerekir. Aslında, bu ürünlerin tamamı reklâm verenler için tasarlanmıştır. Daha farklı bir ifade ile, reklâm piyasasında medya içeriği, tamamen pazarlanabilir özel bir maldır. Bu piyasada arz noktasında, gerek yasal gerekse maliyet açısından sinırlamalar olduğundan, reklâm sahası konusunda reklâm verenler arasında bir rekabet bulunmaktadır. (Sjurts, 2002:5) Schiller, enformasyon sürecinin reklam endüstrisi tarafından yürütüldüğünü ve reklam endüstrisinin de belli başlı Amerikan şirketleri tarafından beslendiğini belirtmektedir (Schiller, 1993:74). Türkiye ölçeğinde yaşanan yoğunlaşma, medya endüstrisinde bir elin parmaklarını geçmeyecek sayıda örgütlenmeleri de beraberinde getirmiştir. Sermaye, medya ve 
reklam arasındaki ilişki holdingleşmiş yapıları ortaya çıkartmakta ve holdingleşmiş yapıda medya, reklam harcamalarını azaltarak grupların çıkarlarını korumak için kullanılmaktadır. Aslında bu durum bir bakıma karşılıklı çıkar ilişkisidir. Dallas Smythe'ye göre medya hem kendisi bir emtia olarak pazarda işlem görmekte hem de bir takım ürünlerin pazarlanmasına reklam yoluyla aracılık etmektedir. Buna karşılık reklam endüstrisi ise kuşak programları satın almak yerine izleyicileri toptan olarak medyadan satın almaktadır (Smythe, 1981:32). Medyanın içerikleri kendi çıkarları ve reklam endüstrisinin çıkarlarına göre belirlemesi, karı maksimize etme vurgusunu arttırarak, küresel izleyicilerin ve ürünlerin metalaşmasına hizmet etmektedir.

Bilgisayar teknolojileri ve enformasyonda yaşanan patlama, medya ürünlerindeki çeşitlilikte de karşılığını bulmaktadır. Fakat bu karşılık kapitalist düzenin kar arayışında da belirginleşmektedir. Teknolojilerin ve enformasyonun üretimi, dağıtımı ve tüketimi, kapitalist üretim ve bölüşüm ilişkilerine göre yapılmaktadır. Bilgisayar ve yeni iletişim teknolojilerinin donanım ve içerikleri, kapitalist mülkiyete tâbidir. Reklamcıların etkisi, tıklayıcıların (bilgisayar ve internet kullanıcılarının) gelir düzeyleri ve harcama kapasiteleri belirleyici yapısal faktörlerdir. $\mathrm{Bu}$ alanda faaliyet gösteren medya şirketleri küresel kapitalizmin kurulu koşulları altında çalışıllar, çalışmak zorundadırlar (Webster, 1995:77).

\section{İKİLI MALLAR OLARAK MEDYA ÜRÜNLERİ}

Medya ürünleri, çok geniş bir yelpazede çeşitlenmelerinin yanı sıra, çoklu kullanıma da açıktırlar. Bu durum, medya ürünlerinin ikili mal olarak değerlendirilmesine sebep olmaktadır. Genellikle medya ürünleri, iki farklı piyasadan beslenmekte, iki farklı piyasaya arz edilmektedir.

Bu piyasalardan ilki, ürünün içeriğindeki bilgi, haber, eğlence gibi unsurları için talep edildiği tüketici piyasasıdır. Hemen hemen tüm medya ürünlerinin içinde bulunduğu ikinci piyasa ise reklam piyasasıdır. Bu piyasa, yukarıda sözünü ettiğimiz birinci piyasa ile senkronize çalışmaktadır. Aynı ürünün farklı beklentileri olan kitleler tarafından farklı amaçlarla kullanılıyor olması, reklam oranlarına yansımaktadır. Reklamcılar, talep edilen ürünün niteliğine ve okur/izleyici/dinleyici profiline göre reklam tarifelerini ve zamanlarını ayarlamaktadır. (Picard, 2005: 54) Bu durum, medyayı, dinleyiciler ve reklam verenler arasında bir köprü olarak tanımlayan olguyu da açıklamaktadır. Dahası, Mc Quail'e göre birinci piyasada maliyetin altında hizmet veren medya endüstrisi, çoğu kez gerçek karlılık rakamlarını ikincil piyasalar olarak tabir edilen, reklam piyasasından karşılamaktadır.(Mc Quail, 1992: 89)

Medya Ekonomisi ve Yönetimi’ne ilişkin çalışmalara bakıldığında, medya ürünleri genel olarak, ikili mallar olarak sınıflandırılan ve birçok medya ürününde bulunan iki temel boyut (tüketici için rıza ve reklam verenler için zaman boyutu) üzerinden değerlendirilmiş ve piyasanın ikili yapısına vurgu yapılmıştır. (Bkz: Picard, 2005; Mc Quail, 1992; Doyle, 2002, Albarran, Arrese, 2003) Öte yandan, Schultz'a göre, en az onlar kadar önemli ve sektördeki kamusal/politik müdahaleyi haklı kılan üçüncü bir boyut daha bulunmaktadır. Daha net ifadelerle, alıcılar ve reklam verenlerin dışında medya ürünleri üçüncü bir temel müşteriye sahiptir. O da "Toplum"dur. Schultz, geleneksel tüketici ürünü ve medya ürünü arasındaki temel farkın, tüm sistemdekileri de içerecek şekilde, "topluma yaptığı etki" olduğunu savunmaktadır. Oysa, medya sadece onu kullananlara ve reklam verenlere değil topluma da hizmet sunmalıdır. (Schultz, 1993:5).

Schultz'u destekler biçimde Bergemann ve Bonatti de, medya ürünlerinin, ekonomik değerinin yanı sıra bir de sosyokültürel değeri olduğuna vurgu yapmaktadır. Film ya da müzik gibi ürünler, toplumun kültürel mirasına aittir. Ayrıca, Bergemann ve Bonatti için haber medyası, çok daha ayrıcalıklı ve önemli bir konumdadır. Onlara göre haber medyası nicelik, nitelik ve ürün yelpazesi gibi çeşitli parametreler açısından, bulunduğumuz toplumun sosyo-politik yapısının değişmesine dahi neden olabilir. (Bergemann, Bonatti, 2010:99) Bir gazete haberi, gişe yapmış bir sinema filmi, popüler olmuş bir müzik albümü ya da en çok satanlar arasına girmiş bir kitap, sadece onu satın alıp tüketenler ve reklam verenler açısından değerli değil; aynı zamanda, toplumda yarattı̆̆ 1 etkiler bakımından da değerlidir. Bu fikir açık bir şekilde, medyanın anayasal haklar tarafından korunan tek ticari sektör olmasının da bir yansımasıdır. 
Fotoğrafa yukarıdan bakıldığında, kültür endüstrisinin; sembolik mallardan ve özündeki kültürel değerlerinden ayrılamayacak olan ekonomik değerlerden oluştuğu görülmektedir. Kültürel medya ürünleri ve diğer kültürel ürünler (geleneksel sanat gibi) arasında sayısız fark olmasına ră̆men; ekonomik bakış açısı, sanat ve ticaret arasındaki ince çizgiyi ayırt etmekte giderek zorlanmaktadır. Neo-liberalizmin kurumsal yapısı ve politik bağlamı içerisinde meydana gelen teknolojik yenilikler (dijitalleşme ve ticarî mal haline gelme) yeni iletişim teknolojilerinin ve medyanın içeriklerinin gelişmesini sağlayan kâr arayışıdır. Bunun yanında iletişimin demokratikleştirilmesi, çeşitlilik ya da teknolojik içeriğe evrensel erişim gibi açıklamalar birer mitten ibarettir (Leye,2009:29). Dolayısıyla toplum boyutu çoğu kez kar arayışına kurban edilmektedir.

\section{SONUÇ}

21. yüzyılda ivme kazanan teknolojik gelişmeler, tüm sektörlerde olduğu gibi medya endüstrisinde de önemli dönüşümlerin kapısını aralamıştır. Her şeyden önce, klasik medya araçları çeşitlenmiş; "yeni medya" teknolojileri sayesinde, geleneksel medya araçlarına oranla çok daha farklı özellikleri bünyesinde barındıran araçların kullanımı yaygınlaşmıştır. $\mathrm{Bu}$ gelişme, medya ürünlerinin de çeşitlenmesine önayak olmuş; birbirinden farklı özellikleri ve doğaları olan birçok medya ürünü tüketiciyle buluşmaya başlamıştır.

Ürün açısından konuya yaklaşıldığında, bir sinema filmi ile bir müzik eseri arasında ya da bir gazete ile bir televizyon dizisi arasında yönetimsel anlamda çok büyük farklılıklar bulunmaktadır. Kimi ürünler yaratıcı işgücü gerektirirken kimisi ileri teknoloji gerektirmekte, kimi ürünler bireysel kullanıma yönelik iken kimisi de kitlelere hitap etmektedir. Ya da kimi ürünlerin değeri, satın alma eylemi ile değil tecrübeyle veya tüketimle ortaya çıkmaktadır. Finansal açıdan yaklaşıldığında, her ürünün farklı bir maliyet yapısı bulunmakta ve dolayısıyla farklı bir satış çabası ve pazarlama faaliyeti gerektirmektedir. Dolayısıyla, karlılık oranları da birbirinden farklı gerçekleşmektedir. Ürünün özelliğine göre yönetim faaliyetleri de çeşitlenmektedir. Çoğu zaman sadece ürün yönetimi yeterli olmazken, marka yönetimi ve süreç yönetimi gibi uzmanlık alanlarına da ihtiyaç duyulmaktadır.

Medya ürünleri, faaliyet gösterdikleri pazar yapısı, içerik çeşitliliği, finansal ve operasyonel özellikleri açısından kendi aralarında ve kendileriyle diğer ürünler arasında farklılıklar göstermektedir. Medya ürünlerinin kendine has doğalarının bir sonucu olan bu farklılıklar, medyada ürün yönetim sürecini de etkilemektedir. Başka bir ifadeyle, tek bir medya ürünü için oluşturulan yönetim süreci, diğer medya ürünü için geçerli olmamakta ve ürün yöneticileri farklı tip medya ürünleri için farklı strateji ve iş modelli geliştirmelidirler.

Medya ürünlerinin zengin karakteri, pazarın değişken, çok sesli yapısı ve tüketici odaklı iletişim yaklaşımı; medya endüstrileri açısından, ürün yönetimini üzerinde önemle durulması gereken bir alan haline gelmiştir. Dolayısıyla, farklı sektörlerde tecrübe kazanmış yöneticiler, standart akademik eğitim almış olsalar bile, medya sektöründe uzun bir adaptasyon süreci geçirmektedirler. Üniversitelerin Medya Ekonomisi ve Yönetimi bölümleri, bu ihtiyacı gidermeye yönelik çalışmalarla, sektördeki medya ve ürün yöneticisi boşluğunu doldurabilirler.

Son olarak ifade etmek gerekir ki modernizm ve küresel kapitalizmin temel stratejisi günümüz toplumlarında arzunun yönlendirilmesi ve her alanda rızanın tekrar tekrar üretilmesidir. Medya endüstrisinin ürettiği ürünler de, modern dünyada küresel pazarlama teknikleriyle "şeyleştirilen" ürünler olarak görülmeli ve bu oluşumdaki egemen gücün yapılanmasına yönelik daha dikkatli bir bakış açısı gerekmektedir. Zira medya ürünleri ve onların üretiminde söz sahibi olan güçler, ürünlerin biçim ve içeriklerini tasarlarken bu bakış açısına göre yönetim faaliyetlerini şekillendirmektedir. 


\section{KAYNAKLAR}

Albarran, A., Arrese, A. (2003). Time And Media Markets, Lawrence Erlbaum Associates, New Jersey.

Adorno, T.W. (2003), “Kültür Endüstrisini Yeniden Düşünürken”, Cogito Dergisi, Çev: Bülent O. Doğan, İlkbahar-Yaz, Sayı:36, s.12.

Adorno, T.W. (2007), Kültür Endüstrisi, İletişim Yayınları, İstanbul.

Bergemann, D. Bonatti, A. (2010), "Targeting İn Advertising Markets: Implications For Offline Versus Online Media.” Cowles Foundation For Research İn Economics, Yale University.

Clemons, E. (2008), "How Information Changes Consumer Behavior And How Consumer Behavior Determines Corporate Strategy" Journal Of Management Information Systems, Fall2008, Vol. 25 Issue 2, P13-40

Doherty, N., (2010). "The Measurement Of Output And Economies Of Scale İn Property-Liability Insurance," Journal Of Economics, 48: 390-402.

Doyle, G. (2002). Understanding Media Economics, Sage Publishing, London.

Etzioni, A (2008), "Twenty Years Of "The Moral Dimension: Toward A New Economics" SocioEconomic Review, 2008, Vol. 6 Issue 1, P135-135

Giddens, A. (2006). Sociology. 5th Edition. Cambridge: Polity Press.

Herman, E. S. ve Chomsky, N. (1988). Mannufacturing Consent: The Political Economy of the Mass Media. New York: Random House.

Horkheimer, M. (1996), Akıl tutulması, Metis Yayınları, İstanbul.

Ittner, Christopher D. And David F. Larcker (2009), "Product Development Cycle Time And Organizational Performance", Joumal Of Marketing Research, Vol. 34, February, No.L, Pp.L3-23.

Kayıkçı, M. (2007), “Adorno’nun Kültür Endüstrisi Kavramı Üzerine”, Bilim, Eğitim ve Düşünce Dergisi, Cilt:7, Sayı: 2.

Kotler, P., (1987), Pazarlama Yönetimi, Çözümleme, Planlama Ve Denetim, Bilimsel Yayınlar Derneği, Cilt 2, Ankara.

Larrain, J.(1995). İdeoloji Ve Kültürel Kimlik, (Çev. N. Nur Domaniç )., İstanbul: Sarmal.

Leye, V. (2009). "Information and Communication Technologies for Development: A Critical Perspective”. Global Governence. Volume: 15. Issue: 1. Page Number: 29-32.

Mc Quail, Dennis. (1992), Media Performance, Mass Communication And The Public İnterest, Sage Publications, London.

Manovich, L. (2001), The Language of New Media, Cambridge, Mass.: MIT Press.

Marcuse, H. (1997), Tek Boyutlu İnsan, İdea Yayınevi, İstanbul.

Mattelard, A. (1979), Multinational Corparations and the Control of Culture, The İdeological Apparatuses of Imperialism, New Jersey, Humanities Press. 
Picard, R.(2005a). Media Product Portfolios: Issues İn Management Of Multiple Products And Services, Lawrence Erlbaum, New Jersey.

Picard, R.(2005b) "Unique Characteristics And Business Dynamics Of Media Products", Journal Of Media Business Studies, 2(2), P.61-69.

Schiller, H. (1993). Zihin Yönlendirenler. Çev: Cevdet Cerit, İstanbul, Pınar Yayınları.

Schultz, D. E. (1993). Strategic Newspaper Marketing (2nd Ed.), International Newspaper Marketing Association, Reston, Va.

Shapiro, C., H. R. Varian (1999), Information Rules: A Strategic Guide To The Network Economy, Harvard Business School Press, Boston:Massachusetts.

Smythe, D. (1981). "On the Audience Commodity and Its Work." Dependency Road: Communications, Capitalism, Consciousness and Canada. Norwood, N.J: Ablex Publications. pp.225.

Sullivan, A. (2003), Economics: Principles İn Action, Upper Saddle River, Pearson Prentice Hall, New Jersey.

Sjurts, I. (2002). "Similarity Despite Variety. Aneconomic Explanation Of The Tendency Towards Standarisation İn The Media Markets.", 5th World Media Economics Conference, May 9-11, Finland, P.2-21.

Tayler, P, (2009) The Development Of The Theory Of Economies Of Scale, Warwick Papers İn Management, Vol:2, 199-215.

Yaylagül, L. (2013), "Bilgisayar ve İnternetin Ekonomi Politiği”, Global Media Journal, Fall-2013, pp.214-236.

Wade, J.R. (1993). "Brave New World of Communications Technology". Security Management. Volume: 37. Issue: 3. March. Page Number: 4.

Webster, F. (1995). Theories of the Information Society, London, Routledge.

Ziggers, Gerrit W. (2005), "Radical Product Innovation", Journal Of Products Marketing, Vol.11, Pp.43-65. 